\title{
Are Internal Cash Flows the Source of Advertising Expenses?:
}

\section{Evidence from Korea}

\author{
Gee-Jung, Kwon \\ Division of Economics and Commerce, Hanbat National University \\ San 16-1, Duckmyoung-Dong, Yuseong-Gu, Daejeon 305-719, Republic of Korea \\ Tel: 82-42-821-1337Ｅ-mail: geejung@hanmail.net
}

Received: April 11, $2011 \quad$ Accepted: May 27, $2011 \quad$ Published: October 1, 2011

doi:10.5539/ijbm.v6n10p37 URL: http://dx.doi.org/10.5539/ijbm.v6n10p37

\begin{abstract}
The study examines the relationship between advertising expenses and internal cash flow using 8,346 sample companies listed on the Korean stock markets over the period from 1999 to 2008. For the precise test, the study further partitions the total samples into two or four portfolios based on stock markets, firm size, and the magnitude of advertising intensity (advertising expense/total sales).

The main findings of this study are twofold; First, internal cash flow is significantly associated with advertising expenses in subgroups such as high advertising firms and firms listed in KRX. This result suggests that internal cash flow may be one of the core sources of advertising expenses. Second, the relation degree of internal cash flow and advertising expenses is mainly depending on the magnitude of advertising expense intensity. It shows more significantly positive relationship for firms with higher advertising expenses intensity than for firms with lowers.

The important contribution of this paper is exploring the sources of advertising investment in listed Korean stock market and this study is one of limited number of studies that investigates the main source of advertising expense in Korean stock markets.
\end{abstract}

Keywords: Advertising expense, Advertising investment, Advertising expense intensity, Internal cash flow

\section{Introduction}

Generally, advertising includes some promotional activities to help selling a product or service to customers. Recent years most companies usually spend their money on making various commercial films or the maintenance of a commercial website to announce brand name and corporate image (Moon, 1999; Kloss, 2001; Jang, 2002; Corstjens \& Merrihue, 2003). Therefore advertising expenses are valuable or crucial factors in businesses because they can lead to additional promotion of firms' future cash flows by providing important information about product and service to customers.

As a result, many prior literatures have investigated the value relevance of advertising expenses. For example, Peles(1971), Abdel-Khalik(1975), Clarke(1976), Ross(1983), Hirschey and Weygandt(1985), Lee(1994), Paek and Jeon(2004), Chung and Cho(2004), Lee and Choi(2007) document that advertising expenses are positively related to firm value. These empirical researches about advertising expenses have mainly focused on the value relevance or capitalization of advertising expenses.

But researchers in accounting field are not interested in investigating the source of advertising expenditure that promoting firm value. Even though many researchers and professionals recognize the importance of advertising expense, they just focus on the result of advertising investment; they did not explore the source of it. If advertising is important and have value relevance, it is inevitably need to know what is the main factor that promoting advertising investment.

All firms in real world have suffering financial constraint. Because most firms are financially constrained, internal cash flow can allow companies to increase their own investment. Himmelberg and Petersence (1994) motivated by this financial constraint in $R \& D$ investment. They document that internal cash flow can relax 
financial constraint and allow firms to invest their R\&D project. Similar researches have performed the source of variable investment such as inventory (Carpenter, Fazzari, and Petersen, 1994), stocks (Almeida, Campello, and Weisbach, 2004).

This paper extends this discussion to advertising expense. Exploring the source of advertising expenditure can give us the data of identifying variations of cash flow when firm have opportunity of advertising investment.

To do this, the paper explores the association of advertising expense and internal cash flow over the period of 1999-2008 in the listed Korean stock market. More precisely, this paper focuses on the effect of internal cash flow on advertising expense. For this, the study replicates the empirical model of Himmelberg and Petersence (1994). For more precise analysis, this paper splits samples into firms listed in KRX (Korea Exchange)/KOSDAQ (Korea Securities Dealers Automated Quotation) markets, big/small and medium size firms and high advertising/low advertising firms.

The empirical results shows internal cash flow is the core source of advertising expense in KRX/KODSAQ groups and high advertising groups. The results also indicate that firms with more high advertising intensity are more highly associated with internal cash flow than firms with lower advertising intensity.

The paper organized as follows. In the next section, this study reviews related previous literatures examine the association between advertising expense and cash flow. Section 3 describes hypothesis and empirical method. Section 4 discusses the empirical results. Section 5 summarizes the study and concludes with a discussion of this paper's limitations and contributions.

\section{Literature Review}

If firms are financially constrained, internal cash flow can be the only source of their own investment. In the same context, many literatures have documented the role of internal cash flow in R\&D investment (Akerlof, 1970; Bhattacharya and Ritter, 1983; Myers and Majluf, 1984; Bhagat and Welch, 1995, Kong and Kim, 2000).

For example, Himmelberg and Petersen (1994) document internal cash flow is the core factor of R\&D investment for small and high technology firms. Kong and Kim (2000) also investigate the empirical relationship between R\&D investment and internal cash flow in listed Korean firms. They show that internal cash flow is significant variable of R\&D investment for Chaebul firms.

However, most prior literatures do not focus on advertising expenditure. They offer no clear evidence and conclusions about whether internal cash flow increase advertising investment that can create firms' future cash flow.

Alike with R\&D investment, advertising expense can promote firm value and create potential intangible asset that may not be measurable by increasing future demand and brand loyalty (Peles, 1971; Abdel-Khalik, 1975; Clarke, 1976; Ross, 1983; Hirschey and Weygandt, 1985; Lee, 1994; Paek and Jeon, 2004; Chung and Cho, 2004; Lee and Choi, 2007).

Even though advertising investment is significant value relevance factor, it is difficult to finance because it is an intangible investment for future promotion of demand and brand value. Some report that the return to advertising expenditure is very rapid (Almeida and Campello, 2007), but others are not (Johnson, 1967; Newman, 1968; Picconi, 1977; Bulitz and Ettredge, 1989; Choi, 1994; Jeong and Lee, 1996; Kwon and Lee, 1999; Yook, 2003; Park, 2005; Kim et al., 2006) .

In this context, it is necessary to find whether internal financing can be the source of advertising investment. So the study mainly focuses on advertising expense and examines whether it can promote firms' advertising opportunities.

\section{Hypothesis and Empirical Model}

\subsection{Research Hypothesis}

This paper examines the association between advertising expenditure and internal cash flow over the period from 199 to 2008 in the listed Korean security market. To do this, the paper tests following hypothesis;

H: Internal cash flow has significant relationship with advertising investment

This hypothesis is to examine whether internal cash flow has a significant impact on advertising investment. Internal cash flow is defined as the sum of earnings and depreciation cost published on income statement and manufacturing statement. Internal cash flow is mainly increased by revenues from operating or the disposal of firms' assets. Therefore, if sales from ordinary operating increase or firms dispose of their assets, firms have more opportunity to do advertising investment. 
This paper first examines the empirical relationship between advertising expenditure and internal cash flow for entire sample. To know more precisely the reason for unknown relation this study proceeds to test differences in the advertising investment-internal cash flow relation across subsamples grouped by Market (KRX vs. KOSDAQ), size (Big vs. Small and Medium), and advertising intensity (High vs. Low). Splitting the sample into subsamples by firm characteristics is a general approach and can be informative in empirical research. By doing this, this paper can find systematic evidence and any relation that still uncovered.

\subsection{Empirical Model}

This paper replicates Himmelberg and Petersen (1994)'s empirical model and other prior literatures (Kong and Kim, 2000; Choi, 2007). This model is for the test of the empirical relationship between advertising investment and internal cash flow.

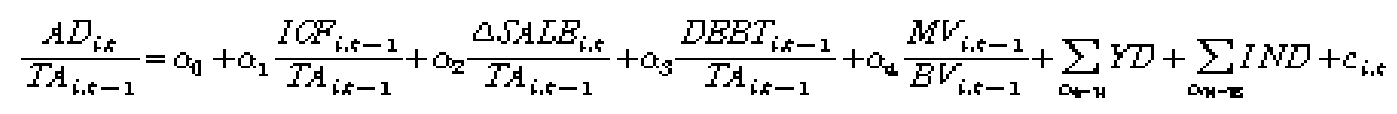

Where, for sample firm $i$,

$$
\begin{aligned}
& A D_{i, t}=\text { Total advertising expense in period } \mathrm{t}, \\
& T A_{i, t-1}=\text { Total assets at the end of year } \mathrm{t}-1 \text {, } \\
& I C F_{h, t}-1=\text { Internal cash flow in period } \mathrm{t} \text { (earnings }+ \text { depreciation cost), } \\
& \triangle S A L E_{b *}=\text { Change of Sales (sales of year } \mathrm{t} \text { - sales of year } \mathrm{t}-1 \text { ), } \\
& D E B T_{\mathrm{i}, t-1}=\text { Total debt at the beginning of year } \mathrm{t} \text {, } \\
& M V_{\text {, }, t-1}=\text { Market value of equity at the beginning of year t, } \\
& B V_{i, t-1}=\text { Book value of equity at the beginning of year } t \text {, } \\
& Y D=\text { Year dummy, } \\
& I N D=\text { Industrial dummy, } \\
& g_{i, t}=\text { Error term }
\end{aligned}
$$

Advertising investment $\left(A D_{h ;}\right)$ is measured by the sum of advertising expense on income statement and statement of cost of goods manufactured in period t. Total asset $\left(T A_{i, t}-1\right)$ is defined as the sum of assets on balance sheet at the end of year $\mathrm{t}-1$. Internal cash flow calculated by the sum of earnings of income statement and depreciation of income statement and cost of goods manufactured in period t. Change of Sales $\left(\triangle S A L E_{i, *}\right)$ is defined as variation between current year sales and prior year sales. Debt $\left(D E B T_{i, t}-1\right)$ is carrying amount of total debt on balance sheet at the beginning of year t, and Market value of equity $\left(W V_{i, t}-1\right)$ is total market value of equity at the beginning of year t. Book value $\left(E V_{b, t}-1\right)$ is carrying amount of equity value on balance sheet at the beginning of year $t$.

\section{Empirical Results}

\subsection{Sample Selection}

This study obtains data on advertising expenditure, internal cash flow, and other variables from KIS-VALUE II (Korea Investors Service-Financial Analysis System). The data spans over the period of 1999-2008. This paper excludes sample data without variables used in empirical analysis. This study also excludes sample firms included in public business, banking and impaired capital firms on KIS-VALUE II database. This paper deletes outliers automatically with Cook's Distance greater than 0.5 and absolute value of student residuals greater than 1. $<$ Table $1>$ shows sample data used in this paper.

\section{Insert Table 1 about here}

\subsection{Empirical Results}

\subsubsection{Descriptive Statistics}

$<$ Table $2>$ shows descriptive statistics for the sample of advertising investment, internal cash flow, changes of sale, debt ratio, and growth opportunity. This study includes 8,346 firm-year samples for the period of 1999-2008. 
Means of advertising investment is 0.061 , and its maximum value is 40.403 . Means of internal cash flow is 0.093 ; its minimum is 0.000 and maximum is 28.535 . Total means of changes of sale is 0.159 ; its minimum and maximum value is -8.092 and 8.380 respectively. Standard deviation of debt ratio is 0.190 ; its mean, minimum and maximum value is $0.423,0.010$, and 0.999 respectively. Means of growth opportunity is 1.454 ; its standard deviation, minimum, and maximum value are $3.096,0.024$, and 116.889 respectively.

\section{Insert Table 2 about here}

\subsubsection{Correlation Analysis}

$<$ Table $3>$ presents the results of Pearson correlation analysis. Dependent variable, Advertising investment is positively correlated to internal cash flow, changes of sale, growth opportunity at the $1 \%$ level of significance, while it is negative correlated with debt ratio at the $5 \%$ level of significance.

Internal cash flow, main independent variable, is positively correlated to changes of sale and growth opportunity at the $1 \%$ level of significance, whereas it shows negatively correlated with debt ratio at the $10 \%$ level of significance.

\section{Insert Table 3 about here}

\subsubsection{The Effect of Internal Cash Flow on Advertising Investment: Total sample firm}

This study estimates empirical model for the total sample firms. $<$ Table $4>$ presents the effect of internal cash flows on advertising investment using a multiple linear regression model.

The coefficient of internal cash flow is positively significant at a level of $10 \%$. The change of sale shows positive relationship with advertising investment at $1 \%$ level of significance while debt ratio shows negative relationship with dependent variable at $10 \%$ level of significance and growth opportunity is not significantly related to advertising investment.

This result presents that internal cash flow is weakly related to advertising investment in total firm sample while the change of sale is significantly related to dependent variable. The result also indicates that internal cash flow is not dominant advertising relevant factor with respect to change of sale in Korean listed market. This result does not support hypothesis [Internal cash flow has significant relationship with advertising investment] in total sample regression.

\section{Insert Table 4 about here}

\subsubsection{The Effect of Internal Cash Flow on Advertising Investment: KRX vs. KOSDAQ}

The paper examines the advertising relevance of internal cash flow by focusing on listed Korean markets (KRX vs. KOSDAQ). $<$ Table 5> presents the empirical relationship between advertising investment and internal cash flow by splitting total samples into two groups (KRX/ KOSDAQ).

The coefficient of internal cash flow is positively significant at a level of $5 \%$ and $1 \%$ in KRX and KOSDAQ groups respectively. However, the coefficients of change of sale and debt ratio are not significant in both groups. The coefficient of Growth opportunity is positively significant at $1 \%$ level of significance only in KOSDAQ group.

This result indicates that internal cash flow is significant variable of advertising investment both in KRX and KOSDAQ groups. Furthermore, the result suggests that internal cash flow is more advertising investment relevant factor in KODAQ sample group than KRX sample group.

\section{Insert Table 5 about here}

\subsubsection{The Effect of Internal Cash Flow on Advertising Investment: Big vs. Small\&Medium}

The paper tests the relationship between advertising investment and internal cash flow by focusing on the size of sample firms (Big firm/Small\&Medium firm). $<$ Table 6> shows the test result of empirical relationship between advertising investment and internal cash flow by dividing total samples into two subgroups (Big firm/Small\&Medium firm).

The coefficient of internal cash flow shows no significant estimates both Big firm/Small\&Medium firm groups. And changes of sale have no significant relationship with advertising investment both in Big firm/Small\&Medium firm groups too. However, the coefficients of debt ratio and growth opportunity are significant in Big firm group and Small\&Medium firm group respectively. The coefficient of Growth opportunity is positively significant at $1 \%$ level of significance only in KOSDAQ group. This result suggests that 
internal cash flow is not a significant variable of advertising investment both in Big firm/Small\&Medium firm groups.

\section{Insert Table 6 about here}

\subsubsection{The Effect of Cash Flows on Advertising Investment (High advertising vs. Low advertising)}

This study tests the empirical relationship between advertising investment and internal cash flow by focusing on the magnitude of advertising investment (High advertising sample firm/Low advertising sample firm). <Table 6> shows the advertising relevance of internal cash flow by dividing total samples into two subgroups such as high advertising sample and low advertising sample.

The coefficients of internal cash flow is positively significant at a level of $1 \%$ in high advertising firm, while it does not show significant relationship with advertising investment in low advertising firm. And the coefficients of change of sale shows positively significant relationship with dependent variable at a level of $1 \%$ in both sample groups (High advertising sample firm/Low advertising sample firm). However, the coefficient of debt ratio is negatively related to advertising investment at a level of $1 \%$ significance only in low advertising firm group. On the other hand, Growth opportunity shows positive relationship with dependent variable only in high advertising group. This result indicates that internal cash flow has positively significant advertising relevance only in high advertising sample firm, while it has no significant relationship with advertising investment in low advertising sample firm.

\section{Insert Table 7 about here}

4.2.7 The Effect of Cash Flow on Advertising Investment (The magnitude of advertising investment: 4 subgroups)

$<$ Table $8>$ shows test results of the empirical relationship between advertising investment and internal cash flow by splitting sample data into four subgroups $\left(1^{\text {st }}\right.$ quarter, $2^{\text {nd }}$ quarter, $3^{\text {rd }}$ quarter, $4^{\text {th }}$ quarter $) .1^{\text {st }}$ quarter is the highest advertising investment sample group, $2^{\text {nd }}$ quarter is the second highest advertising investment group, $3^{\text {rd }}$, $4^{\text {th }}$ quarters are the third and the fourth highest sample group in advertising investment respectively.

$<$ Table $8>$ presents the coefficients of internal cash flow is positively related to advertising investment at a $1 \%$ level of significance in $1^{\text {st }}, 2^{\text {nd }}, 3^{\text {rd }}$ groups while it is not significant in $4^{\text {th }}$ group. Furthermore, the magnitude of internal cash flow's coefficients grow bigger as advertising investment grows higher. The coefficients of change of sale show positively significant relationship with dependent variable at a level of $10 \%, 1 \%, 1 \%$, and $1 \%$ in $1^{\text {st }}$, $2^{\text {nd }}, 3^{\text {rd }} 4^{\text {th }}$ groups respectively.

The coefficients debt ratios also show significant relationship with advertising investment at a level of $1 \%$ significance in $2^{\text {nd }}, 3^{\text {rd }}, 4^{\text {th }}$ groups while $1^{\text {st }}$ quarter group does not present significant relationship with dependent variable. The coefficients of growth opportunity present significantly positive relationship with dependent variable only in $1^{\text {st }}$ quarter group at a $1 \%$ level of significance while $3^{\text {st }}$ and $4^{\text {th }}$ quarter group show negatively significant relationship with advertising investment at a level of $5 \%$ and $10 \%$.respectively.

This result indicates that internal cash flow has positively significant advertising relevance only in $1^{\text {st }}, 2^{\text {nd }}, 3^{\text {rd }}$ quarter sample groups, while it has no significant relationship with advertising investment in lowest advertising sample firm ( $4^{\text {th }}$ quarter group). This suggests as advertising investment grows, the dependence of firms on internal cash flow also grow, while the dependence of firms on debt shrink.

\section{Insert Table 8 about here}

\section{Conclusion}

This paper investigates the association between advertising investment and internal cash flow in listed Korean firms over the period from 2000 to 2008. To do this study performs multiple regression model replicating Himmelberg and Petersence (1994).

This paper tests hypothesis (Internal cash flow has significant relationship with advertising investment). To test more precisely the reason for unknown relation, this paper performs examination about differences in the advertising investment-internal cash flow by separating total sample data into subsample grouped by firm characteristics (Market: KRX vs. KOSDAQ, size: Big vs. Small and Medium, advertising intensity: High vs. Low)

This study does not show supportive evidence for study hypothesis, but it shows following important findings;

(1) Internal cash flow is significant variable of advertising investment both in KRX and KOSDAQ groups. And it has more impact on KODAQ sample group than KRX sample group. 
(2) Internal cash flow is not a significant variable of advertising investment both in Big firm and Small\&Medium firm groups.

(3) Internal cash flow has positively significant impact on advertising investment only in high advertising sample firm, while it has no significant relationship with advertising investment in low advertising sample firm.

(4) Internal cash flow has positively significant relationship with advertising investment only in $1^{\text {st }}, 2^{\text {nd }}, 3^{\text {rd }}$ quarter sample groups, while it has no significant impact on advertising investment in lowest advertising sample firm $\left(4^{\text {th }}\right.$ quarter group). This results indicates as advertising investment grows, the dependence of firms on internal cash flow also grow, while the dependence of firms on debt shrink.

Finally, this study finds an important role for internal cash flow in explaining advertising investment and indicates that internal cash flow can be the important source of advertising investment in listed Korean stock markets.

The core contribution of this paper is examining the empirical association between internal cash flows and advertising investment in listed Korean security market. But this result is just limited only to Korean firms and certain short periods (2000-2008). Therefore a following research should extend research periods and international data including many countries' data such as Europe, U.S.A, China, and Japan and it is necessary to perform international comparative analysis.

\section{References}

Abdel-khalik, A. R. (1975). Advertising Effectiveness and Accounting Policy. The Accounting Review, 50, 657-670.

Akerlof, G. A. (1970). The Market for "Lemons": quality, uncertainty, and the market mechanism. Quarterly Journal of Economics, Vol. 84, 488-500. http://dx.doi.org/10.2307/1879431

Almeida, H., M. Campello and M. S. Weisbach, (2004). The Cash Flow Sensitivity of Cash. Journal of Finance, 59:1777-804.

Bhagat, S., and I. Welch. (1995). Corporate research \& development investments international comparisons. Journal of Accounting and Economics, 19, 443-470. http://dx.doi.org/10.1016/0165-4101(94)00391-H

Bhattacharya, S., and J. R. Ritter. (1983). Innovation and communication: signalling with partial disclosure. Review of Economic Studies, 50, 331-346. http://dx.doi.org/10.2307/2297419

Bublitz B., and M. Ettredge. (1989). The Information in Discretionary Outlays: Advertising, Research and Development. The Accounting Review, 64 (January), 108-124.

Carpenter, R. E., S. M. Fazzari, and B. P. Petersen. (1994). Inventory Investment, Internal-Finance Fluctuations, and the Business Cycle. Brookings Papers on Economic Activity, 2:75-138.

Choi, J. H. (1994). The Empirical Value Relevance of Advertising Expense and R\&D Expense - Using Torbin-Q. Korean Accounting Review, 19, 103-124.

Chung, H. Y., and S. I. Cho. (2004). Value-Relevance of Accounting Information on Intangibles. Korean Accounting Review, 29, 3, 1-31.

Clarke. (1976). Econometric Measurement of the Duration of Advertising Effect on Sales. Journal of Marketing Research, November, 347-357.

Corstjens, M., \& Merihue, J. (2003). Optimal Marketing. Harvard Business Review, 81, October, 114-121.

Himmelberg, C. P., and B. C. Petersen. (1994). R\&D and internal finance: a panel study of small firms in high-tech industries. Review of Economics and Statistics, 76, 38-51. http://dx.doi.org/10.2307/2109824

Hirschey, M., and J. J. Weygandt. (1985). Amortization Policy for Advertising and Research and Development Expenditures. Journal of Accounting Research, 23, 326-335. http://dx.doi.org/10.2307/2490921

Jang, S. J. (2002). Grobal Business: International Business in age of Global Competition. Pakyoungsa: Seoul.

Jeong, K. S., and J, G. Lee. (1996). The impact of Advertising and R\&D Expense on Firm Value. Korean Industrial Economic Review, 9, 1, 395-417.

Johnson, J., A. (1967). Consequential Approach to Accounting for R\&D. Journal of Accounting Research, 3, 164-172. http://dx.doi.org/10.2307/2490251

Kim, Y. Y., W. K. Jang, and H. H. Kee. (2006). A Study on the Impact of the Intangible Assets on the Firm Value. DAEHAN Journal of Business, 19, 1, 199-216. 
Kloss, I. (2001). Advertising Worldwide. Springer: Berlin, Germany. http://dx.doi.org/10.1007/978-3-642-56811-4

Kong, M, J., and, P. K. Kim. (2000). Corporate R \& D Investment and Cash Flows. Asia Pacific Journal of Small Business, 111-135.

Kwon, S. Y, and S. H. Lee. (1999). The Impact of R\&D Costs and Advertising Expenditure on the Firms' Market Value. Journal of Business Research, 14, 2, 239-263.

Kyu Wan, Choi. (2007). Corporate Cash Flow and R\&D Investment. Korean Securities Association Business Conference, 1, 312-346.

Lee, K. B., and M. W. Choi. (2007). Determinants of Abnormal Income. Journal of Business Research, 22, 4, 175-208.

Lee, S. M. (1994). The Income Expectation of R\&D Expense and Advertising Expense: Focusing on Ordinary Income. Dankook University Doctroal Degree Paper.

Moon, B. Y. (1999). Consumer processing of foreign advertising. Korean Journal of Advertising, 10, 1, $117-132$.

Myers, S. C., and N. S. Majluf. (1984). Corporate financing and investment decisions when firms have information that investors do not have. Journal of Financial Economics, 13, $187-221$. http://dx.doi.org/10.1016/0304-405X(84)90023-0

Newman, M. (1968). Equating Return from R\&D Expenditures. Financial Executive, 26-33.

Paek, W. S., \& S. I. Jeon. (2004). Accounting Methods for Intangible Expenditures, Persistence of Abnormal Earnings and Equity Valuation. Korean Accounting Review, 29, 3, 199-226.

Park, K. R. (2005). Comparison of Correlations in the Effects of Advertising Expenses after Asian Financial Crisis. Business Education Review, 38, 331-353.

Peles, Y. (1971). Rates of Amortization of Advertising Expenditures. Journal of Political Economy, 79 (October), 1032-1058. http://dx.doi.org/10.1086/259813

Picconi, M.J. (1977). A Reconsideration of the Recognition of Advertising Assets on Financial Statements. Journal of Accounting Research, 15 (Autumn), 317-326. http://dx.doi.org/10.2307/2490357

Ross, S. A. (1983). Accounting and Economics. The Accounting Review (April), 375-380.

Yook, K. H. (2003). The Review of Economic Effect R\&D Expense and Advertising Expense. Journal of Business Research, 18, 3, 219-251.

Table 1. Sample selection

\begin{tabular}{|c|c|c|c|c|c|}
\hline Year & KRX & KOSDAQ & Large Firm & $\begin{array}{c}\text { Small\& } \\
\text { medium Firm }\end{array}$ & Total \\
\hline 1999 & 362 & 175 & 273 & 264 & 537 \\
\hline 2000 & 369 & 264 & 297 & 336 & 633 \\
\hline 2001 & 374 & 353 & 329 & 398 & 727 \\
\hline 2002 & 419 & 395 & 354 & 460 & 814 \\
\hline 2003 & 443 & 435 & 377 & 501 & 878 \\
\hline 2004 & 436 & 474 & 385 & 525 & 910 \\
\hline 2005 & 457 & 509 & 397 & 569 & 966 \\
\hline 2006 & 453 & 529 & 391 & 591 & 982 \\
\hline 2007 & 483 & 534 & 404 & 613 & 1,017 \\
\hline 2008 & 410 & 472 & 353 & 529 & 882 \\
\hline Total & 4,206 & 4,140 & 3,560 & 4,786 & 8,346 \\
\hline
\end{tabular}


Table 2. Descriptive statistics of total samples

\begin{tabular}{|c|c|c|c|c|c|c|}
\hline \multicolumn{2}{|c|}{ Variables } & $\mathrm{N}$ & Mean & Std. dev. & Min & Max \\
\hline$\frac{A D_{i, k}}{T A_{i,-1}}$ & $\begin{array}{l}\text { Advertising } \\
\text { investment }\end{array}$ & 8,346 & 0.061 & 0.682 & 0.000 & 40.403 \\
\hline$\frac{T G F_{i, 5-1}}{T A_{i, 5-1}}$ & $\begin{array}{c}\text { Internal Cash } \\
\text { flow }\end{array}$ & 8,346 & 0.093 & 0.348 & 0.000 & 28.535 \\
\hline$\frac{\Delta N A E E_{i, k}}{T A_{i, k-1}}$ & Changes of sale & 8,346 & 0.159 & 0.448 & -8.092 & 8.380 \\
\hline$\frac{D E B T_{i+1}}{T A_{i+1}}$ & Debt ratio & 8,346 & 0.423 & 0.190 & 0.010 & 0.999 \\
\hline$\frac{M V_{i, i-1}}{B V_{i, i-1}}$ & $\begin{array}{c}\text { Growth } \\
\text { opportunity }\end{array}$ & 8,346 & 1.454 & 3.096 & 0.024 & 116.889 \\
\hline
\end{tabular}

1) Variable definition:

$A D_{\text {i, }}=$ Total advertising expense in period t, $T A_{\mathrm{i}, t}-1=$ Total assets at the end of year $\mathrm{t}-1, T C F_{\mathrm{i}, t}-1=$ Internal cash flow in period $\mathrm{t}$ (earnings + depreciation cost), $\triangle S A L E_{\mathrm{b}, \mathrm{t}}=$ Change of Sales (sales of year $\mathrm{t}-$ sales of year $\mathrm{t}-1$ ), $D E B T_{i, t-1}=$ Total debt at the beginning of year $\mathrm{t}, M V_{\mathrm{i}, t}-1=$ Market value of equity at the beginning of year $\mathrm{t}$, $B V_{i, *-1}=$ Book value of equity at the beginning of year $\mathrm{t}, T D=$ Year dummy, $I N D=$ Industrial dummy, $\varepsilon_{i ;}=$ Error term.

Table 3. Pearson correlation analysis

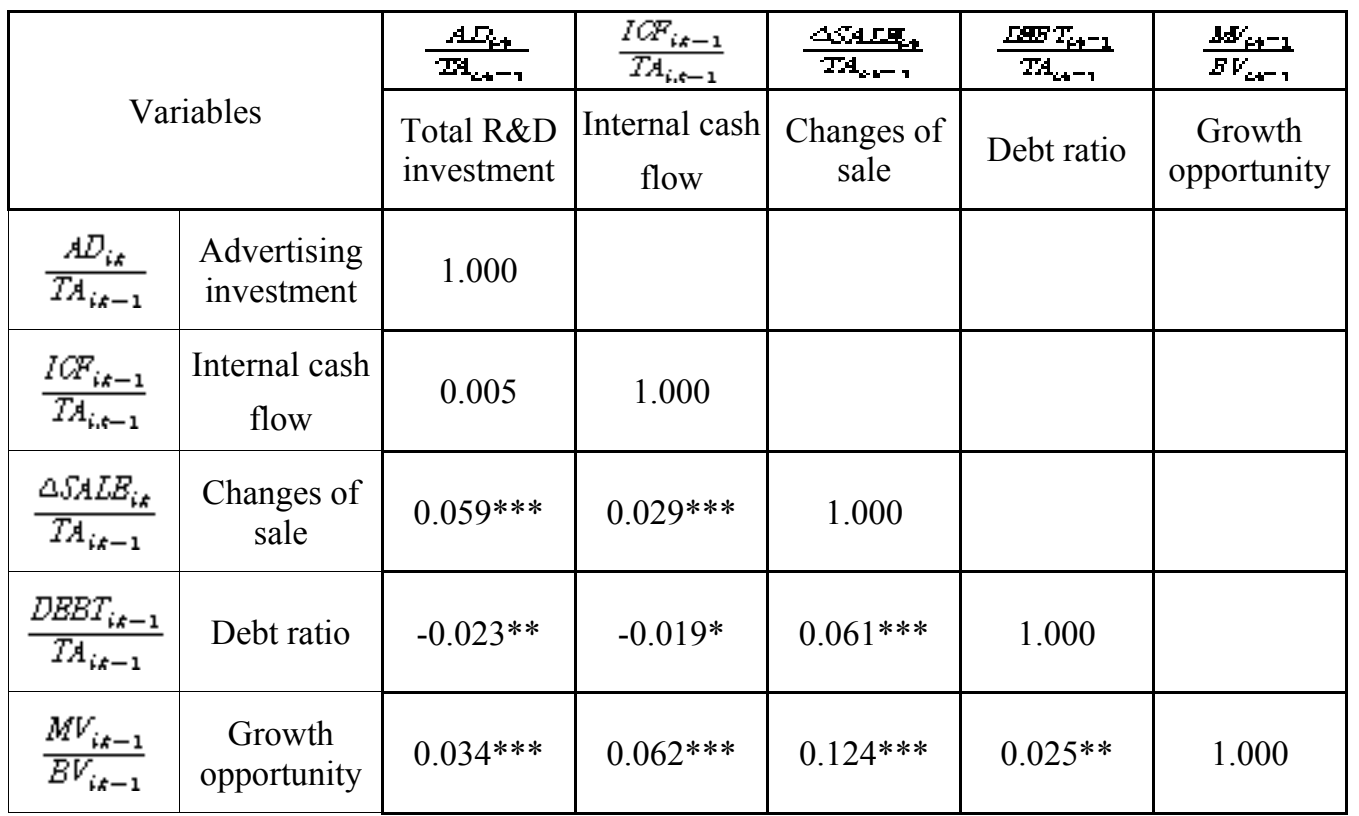

1) Variable definition: $A D_{\mathrm{b}, \mathrm{t}}=$ Total advertising expense in period $\mathrm{t}, T A_{\mathrm{i}, \mathrm{t}}=$ Total assets at the end of year $\mathrm{t}-1$,

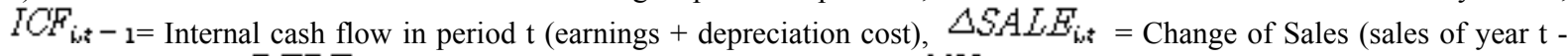
sales of year t-1), $D E B T_{\text {i, }}-1=$ Total debt at the beginning of year t, $M V_{i, t}-1=$ Market value of equity at the beginning of year $t, B V_{i, t}=$ Book value of equity at the beginning of year $t$.

2) $* p<0.1, * * p<0.05, * * * p<0.01$ 
Table 4. The Effect of Internal Cash Flows on Advertising Investment (Total sample firm)

\begin{tabular}{|c|c|c|}
\hline \multicolumn{2}{|c|}{ Variables } & Total Sample \\
\hline \multicolumn{2}{|r|}{ Intercept } & $\begin{array}{c}0.024 * * * \\
(4.75)\end{array}$ \\
\hline$\frac{T F_{i, t-1}}{T A_{i, r-1}}$ & Internal cash flow & $\begin{array}{c}0.006^{*} \\
(1.77)\end{array}$ \\
\hline$\frac{\Delta \int A L E_{i, k}}{T A_{i, t-1}}$ & Changes of sale & $\begin{array}{c}0.009^{* * *} \\
(3.11)\end{array}$ \\
\hline$\frac{D E E T_{i k-1}}{T A_{i k-1}}$ & Debt ratio & $\begin{array}{c}-0.011^{*} \\
(-1.69)\end{array}$ \\
\hline$\frac{M V_{i,-1}}{B F_{i,-1}}$ & Growth opportunity & $\begin{array}{l}0.000 \\
(0.95)\end{array}$ \\
\hline YD & Year dummy & Included \\
\hline IND & Industrial dummy & Included \\
\hline \multicolumn{2}{|c|}{ Number of sample firms } & 8,346 \\
\hline \multicolumn{2}{|r|}{$F-V h r e$} & $4.12 * * *$ \\
\hline \multicolumn{2}{|r|}{$A d i-K^{2}$} & 0.0067 \\
\hline
\end{tabular}

1) Variable definition: $T A_{i, t-1}=$ Total assets at the end of year $\mathrm{t}-1, T C F_{b, t}-\mathrm{l}=$ Internal cash flow in period $\mathrm{t}$ (earnings + depreciation cost), $\triangle S A L E_{b *}=$ Change of Sales (sales of year $\mathrm{t}$ - sales of year t-1), $D E B T_{\mathrm{i} \neq \mathrm{t}-\mathrm{l}}=$ Total debt at the beginning of year $\mathrm{t}, M V_{b, t}-1=$ Market value of equity at the beginning of year $t, B V_{i, t-1}=$ Book value of equity at the beginning of year $\mathrm{t}, T D=$ Year dummy, $I N D=$ Industrial dummy, $\varepsilon_{i, *}=$ Error term.

$2) * p<0.1, * * p<0.05, * * * p<0.01$

3) Research model:

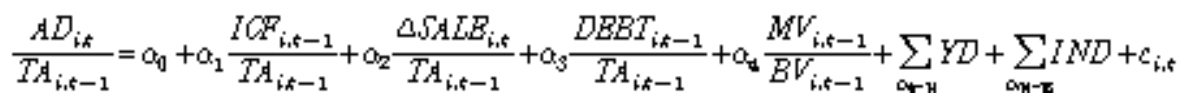


Table 5. The Effect of Internal Cash Flows on Advertising Investment (KRX vs. KOSDAQ)

\begin{tabular}{|c|c|c|c|}
\hline \multicolumn{2}{|c|}{ Variables } & KRX & KOSDAQ \\
\hline \multicolumn{2}{|c|}{ Intercept } & $\begin{array}{l}0.007 \\
(1.43)\end{array}$ & $\begin{array}{l}0.011 \\
(0.95)\end{array}$ \\
\hline$\frac{I C F_{i s-1}}{T A_{i, t-1}}$ & Internal cash flow & $\begin{array}{c}0.005^{* *} \\
(2.01)\end{array}$ & $\begin{array}{c}0.169^{* * *} \\
(3.53)\end{array}$ \\
\hline$\frac{\Delta N A L E_{i, k}}{T A_{i, k-1}}$ & Changes of sale & $\begin{array}{l}-0.002 \\
(-0.73)\end{array}$ & $\begin{array}{l}-0.000 \\
(-0.00)\end{array}$ \\
\hline$\frac{D E B T_{i,-1}}{T A_{i,-1}}$ & Debt ratio & $\begin{array}{l}0.003 \\
(0.47)\end{array}$ & $\begin{array}{l}-0.004 \\
(-0.26)\end{array}$ \\
\hline$\frac{M V_{i, t-1}}{B V_{i t-1}}$ & Growth opportunity & $\begin{array}{l}0.001 \\
(0.94)\end{array}$ & $\begin{array}{c}0.006 * * * \\
(7.95)\end{array}$ \\
\hline YD & Year dummy & Included & Included \\
\hline IND & Industrial dummy & Included & Included \\
\hline \multicolumn{2}{|c|}{ Number of sample firms } & 4,206 & 4,140 \\
\hline \multicolumn{2}{|c|}{$F-\sqrt[V]{\alpha} \omega$} & $2.61 * * *$ & 6.72 \\
\hline \multicolumn{2}{|c|}{$A d i-R^{2}$} & 0.0069 & 0.0245 \\
\hline
\end{tabular}

1) Variable definition: $T A_{b, t-1}=$ Total assets at the end of year $\mathrm{t}-1, I C F_{\mathrm{b}, \mathrm{t}} \mathrm{l}=$ Internal cash flow in period $\mathrm{t}$ (earnings + depreciation cost), $\triangle S A L E_{b, t}=$ Change of Sales (sales of year $\mathrm{t}$ - sales of year t-1), $D E B T_{\mathrm{i}, \mathrm{l}} \mathrm{l}=$ Total debt at the beginning of year $\mathrm{t}, M V_{b, t}-1=$ Market value of equity at the beginning of year $\mathrm{t}, D V_{i, t-1}=$ Book value of equity at the beginning of year t, $Y D=$ Year dummy, $I N D=$ Industrial dummy, $\varepsilon_{b, *}=$ Error term.

2) $* p<0.1,{ }^{* *} p<0.05, * * * p<0.01$

3) Research model:

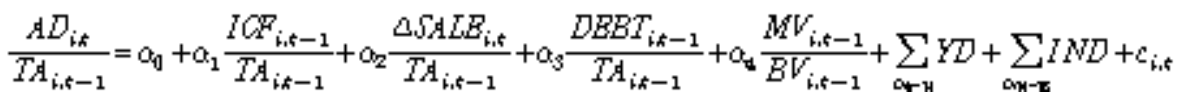


Table 6. The Effect of Cash Flows on Advertising Investment (Big vs. Small\&Medium)

\begin{tabular}{|c|c|c|c|}
\hline \multicolumn{2}{|c|}{ Variables } & Big Firm & Small \& Medium Firm \\
\hline \multicolumn{2}{|c|}{ Intercept } & $\begin{array}{l}0.002 \\
(1.06)\end{array}$ & $\begin{array}{c}0.026^{* *} \\
(2.36)\end{array}$ \\
\hline$\frac{I C F_{i, t-1}}{T A_{i, t-1}}$ & Internal cash flow & $\begin{array}{l}0.001 \\
(0.18)\end{array}$ & $\begin{array}{l}0.006 \\
(1.06)\end{array}$ \\
\hline$\frac{\Delta S A L E_{i, t}}{T A_{i,-1}}$ & Changes of sale & $\begin{array}{l}0.000 \\
(0.23)\end{array}$ & $\begin{array}{l}0.005 \\
(0.89)\end{array}$ \\
\hline$\frac{D E B T_{i=-1}}{T A_{i,-1}}$ & Debt ratio & $\begin{array}{c}0.008 * * * \\
(2.90)\end{array}$ & $\begin{array}{l}0.001 \\
(0.07)\end{array}$ \\
\hline$\frac{M V_{i,-1}}{B V_{i t-1}}$ & Growth opportunity & $\begin{array}{l}0.000 \\
(0.84)\end{array}$ & $\begin{array}{c}0.006 * * * \\
(8.06)\end{array}$ \\
\hline YD & Year dummy & Included & Included \\
\hline IND & Industrial dummy & Included & Included \\
\hline \multicolumn{2}{|c|}{ Number of sample firms } & 3,560 & 4,786 \\
\hline \multicolumn{2}{|c|}{$F-\sqrt{d}[0$} & 5.74 & 5.27 \\
\hline \multicolumn{2}{|c|}{$A d i-R^{2}$} & 0.0236 & 0.0160 \\
\hline
\end{tabular}

1) Variable definition: $T A_{b: t-1}=$ Total assets at the end of year t-1, $I O F_{i, t}-1=$ Internal cash flow in period t(earnings + depreciation cost), $\triangle S A L E_{h * t}=$ Change of Sales (sales of year $\mathrm{t}$ - sales of year t-1), $D E B T_{i, t}-1=$ Total debt at the beginning of year $t, M V_{i, t-1}=$ Market value of equity at the beginning of year $t, B V_{i, t-1}=$ Book value of equity at the beginning of year $\mathrm{t}, T D=$ Year dummy, $I N D=$ Industrial dummy, $\varepsilon_{i, *}=$ Error term.

$2) * p<0.1, * * p<0.05, * * * p<0.01$

3) Research model:

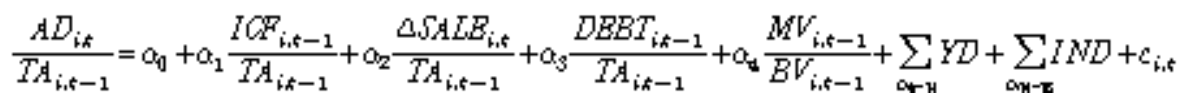


Table 7. The Effect of Cash Flows on Advertising Investment (High advertising vs. Low advertising)

\begin{tabular}{|c|c|c|c|}
\hline & \multirow{2}{*}{ Variables } & \multicolumn{2}{|c|}{ Median } \\
\hline & & High & Low \\
\hline \multicolumn{2}{|r|}{ Intercept } & $\begin{array}{c}0.039 * * \\
(2.16)\end{array}$ & $\begin{array}{c}0.000 * * * \\
(12.36)\end{array}$ \\
\hline$\frac{I C F_{i, 5-1}}{T A_{i, 5-1}}$ & Internal cash flow & $\begin{array}{c}0.251^{* * * *} \\
(4.36)\end{array}$ & $\begin{array}{l}0.000 \\
(0.31)\end{array}$ \\
\hline$\frac{\Delta A_{L} E_{i, k}}{T A_{i,-1}}$ & Changes of sale & $\begin{array}{c}0.024 * * * \\
(2.64)\end{array}$ & $\begin{array}{c}0.000 * * * \\
(5.24)\end{array}$ \\
\hline$\frac{D E E T_{i,-1}}{T A_{i,-1}}$ & Debt ratio & $\begin{array}{l}0.013 \\
(0.55)\end{array}$ & $\begin{array}{c}-0.000 * * \\
(-2.51)\end{array}$ \\
\hline$\frac{M V_{i, 5-1}}{B r_{i, t-1}}$ & Growth opportunity & $\begin{array}{c}0.009 * * * \\
(7.12)\end{array}$ & $\begin{array}{l}0.000 \\
(1.14)\end{array}$ \\
\hline YD & Year dummy & Included & Included \\
\hline IND & Industrial dummy & Included & Included \\
\hline \multicolumn{2}{|c|}{ Number of sample firms } & 3,636 & 4,710 \\
\hline \multicolumn{2}{|r|}{$F-V a r$} & $7.05 * * *$ & $6.05 * * *$ \\
\hline \multicolumn{2}{|r|}{$A d i-R^{2}$} & 0.0293 & 0.0193 \\
\hline
\end{tabular}

1) Variable definition: $T A_{i, t-1}=$ Total assets at the end of year t-1, $T C F_{i, t}-1=$ Internal cash flow in period t (earnings +

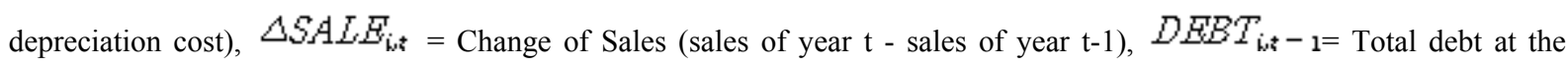
beginning of year $t, M V_{b, t}-1=$ Market value of equity at the beginning of year $t, E V_{i, t-1}=$ Book value of equity at the beginning of year $\mathrm{t}, T D=$ Year dummy, $I N D=$ Industrial dummy,,$_{b, t}=$ Error term.

2) $* p<0.1, * * p<0.05, * * * p<0.01$

3) Research model:

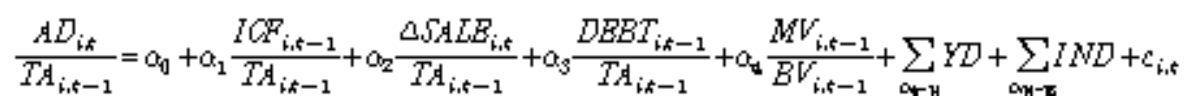


Table 8. The Effect of Cash Flows on Advertising Investment (Quartile)

\begin{tabular}{|c|c|c|c|c|c|}
\hline \multirow{2}{*}{\multicolumn{2}{|c|}{ Variables }} & \multicolumn{4}{|c|}{ Quartile } \\
\hline & & 1 st & $2 \mathrm{nd}$ & $3 \mathrm{rd}$ & 4th \\
\hline \multicolumn{2}{|c|}{ Intercept } & $\begin{array}{c}0.133 * * * \\
(2.91)\end{array}$ & $\begin{array}{c}0.002 * * * \\
(7.09)\end{array}$ & $\begin{array}{c}0.001^{* * * *} \\
(11.61)\end{array}$ & $\begin{array}{c}0.000 * * * \\
(7.52)\end{array}$ \\
\hline$\frac{I C F_{i, t-1}}{T A_{i, t-1}}$ & Internal cash flow & $\begin{array}{c}0.545^{* * *} \\
(3.77)\end{array}$ & $\begin{array}{c}0.004 * * * \\
(4.13)\end{array}$ & $\begin{array}{c}0.000 * * * \\
(2.74)\end{array}$ & $\begin{array}{l}-0.000 \\
(-0.10)\end{array}$ \\
\hline$\frac{\Delta S A L E_{i, k}}{T A_{i, t-1}}$ & Changes of sale & $\begin{array}{c}0.035^{*} \\
(1.66) \\
\end{array}$ & $\begin{array}{c}0.000^{* * *} \\
(8.10)\end{array}$ & $\begin{array}{c}0.000^{* * * *} \\
(9.29)\end{array}$ & $\begin{array}{c}0.000 * * * \\
(5.30)\end{array}$ \\
\hline$\frac{D E E T_{i,-1}}{T A_{i,-1}}$ & Debt ratio & $\begin{array}{l}-0.026 \\
(-0.44)\end{array}$ & $\begin{array}{c}0.000 * * * \\
(8.17)\end{array}$ & $\begin{array}{c}0.000 * * * \\
(4.96)\end{array}$ & $\begin{array}{c}0.000 * * * \\
(3.53)\end{array}$ \\
\hline$\frac{M V_{i t-1}}{B V_{i, t-1}}$ & $\begin{array}{l}\text { Growth } \\
\text { opportunity }\end{array}$ & $\begin{array}{c}0.013 * * * \\
(4.64)\end{array}$ & $\begin{array}{l}-0.000 \\
(-0.07)\end{array}$ & $\begin{array}{c}-0.000 * * \\
(-2.18)\end{array}$ & $\begin{array}{c}-0.000^{*} \\
(-1.92)\end{array}$ \\
\hline YD & Year dummy & Included & Included & Included & Included \\
\hline IND & Industrial dummy & Included & Included & Included & Included \\
\hline \multicolumn{2}{|c|}{ Number of sample firms } & 1,811 & 1,825 & 1,926 & 2,784 \\
\hline \multicolumn{2}{|c|}{$F-V i v e$} & 3.84 & 10.54 & 9.82 & 5.16 \\
\hline \multicolumn{2}{|c|}{$A d i-R^{2}$} & 0.0278 & 0.0865 & 0.0772 & 0.0265 \\
\hline
\end{tabular}

1) Variable definition: $T A_{b:-1}=$ Total assets at the end of year $\mathrm{t}-1, T C F_{i, t}-1=$ Internal cash flow in period $\mathrm{t}$ (earnings + depreciation cost), $\triangle S A L E_{\mathrm{h}, \mathrm{t}}=$ Change of Sales (sales of year $\mathrm{t}-$ sales of year $\mathrm{t}-1$ ), $D E B T_{\mathrm{b}, \mathrm{t}} \mathrm{l}=$ Total debt at the beginning of year t, $M V_{b, t}-1=$ Market value of equity at the beginning of year $t, B V_{i, t-1}=$ Book value of equity at the beginning of year t, $T D=$ Year dummy, $I N D=$ Industrial dummy, $\varepsilon_{i \neq t}=$ Error term.

2) $* p<0.1, * * p<0.05, * * * p<0.01$

3) Research model:

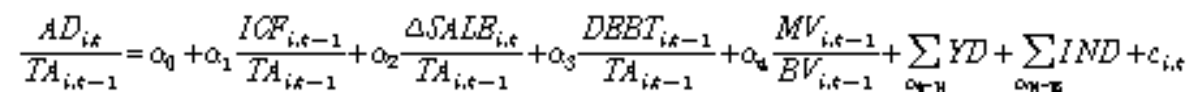

